\title{
Increasing Self-Reliance Through Storytelling
}

\author{
Nopiana $^{1}$, Suryadi $^{2}$, Miftachus Sholikah ${ }^{3}$, Desy Ayuningrum ${ }^{4}$ and Reza Rachmadtullah \\ \{nopiana1201@fkip.unila.ac.id ${ }^{1}$, suryadi@metrouniv.ac.id ${ }^{2}$ \} \\ Universitas Lampung, Jalan Sumantri Brojonegoro No. 1 Bandar Lampung, Indonesia ${ }^{1}$ \\ IAIN Metro, Jl Ki Hajar Dewantara No. 15A Metro Timur Lampung, Indonesia ${ }^{2}$ \\ IAI Pangeran Diponegoro Nganjuk, Jawa Timur, Indonesia ${ }^{3}$ \\ PTIQ Jakarta Selatan, Indonesia ${ }^{4}$ \\ Universitas PGRI Adi Buana, Surabaya, Indonesia ${ }^{5}$
}

\begin{abstract}
The purpose of this research was to determine the process implementation of the method storytelling. This research was a action research using Kurt Lewin research model, which was done during in 2 cycles with 8 meetings in cycle I and 8 meeting in cycle II. Research conducted on March to May 2016. The sample of this study was 12 Group A students comprising 6 male students and 6 female students. Data analysis using quantitative and qualitative data. Quantitative data were analyzed by using descriptive statistic are presented in tables and graphs to seeing the result from the first and second cycle. Qualitative data analysis using the techniques according to Miles and Huberman and data were collected through participant observation using interview, observation and recording, analysis through data reduction, data display, and verification. The result showed an increase in the child's self-reliance after learning with storytelling method. Data attainment of independence of children in pre-cycle which was 29,58. Data had improvement to 36 in cycle I and become 45,83 in cycle II.
\end{abstract}

Keywords : Self-Reliance, Storytelling, Qualitative

\section{Introduction}

Education is the basic capital to prepare a quality human being. According to the Law on National Education, education is a conscious and planned effort to create an atmosphere of learning and learning process so that learners actively develop their potential to have spiritual spiritual power, self-control, personality, intelligence, noble character, as well as skills needed by him, nation and state. According to UNESCO, education should be built with four pillars, namely: learning to know, learning to do, learning to be, and learning to live together.

In essence, learning must last a lifetime, to create a quality generation, education must be done from an early age, in this case through Early Childhood Education (ECE). Early childhood education is intended for children from birth to age 6 years. Since the publication of the latest research results in the field of neuroscience and psychology, early childhood becomes very important considering the potential of intelligence and the basics of a person's behavior formed in this age range. So important this time that early age is often called golden age [1]. This shows how important the effort to develop the full potential of the child. Early Childhood is a new hope for the establishment of the next generation of quality and character as future leaders. One of the values of character that must be implanted in children is independence, research on brain development states that independence is the ability of children to interact with others, control and express feelings, and have the independence to 
perform skills help himself [2]. The fact that occurred in the group A Early childhood education programs Anak Bangsa Serang City which amounted to 12 children shows that the independence of children in doing activities is still very low and still needs to be improved, this is reflected from the behavior of children in doing school activities. This is evident in the following aspects: (1) The ability to make choices, 7 out of 12 children or $60 \%$ still not able to adapt to the environment seen from many that delivered by parents / introduction and still want to keep waiting, and still difficulty in choosing an activity which according to his desire, also looks has not been able to determine what toys will be used also seen when children do activities in class still not able to choose the tools that will be used. (2) Responsible to accept the consequences that accompany the choice, there are still $75 \%$ or as many as 9 out of 12 children have not been able to take responsibility for something chosen, seen when the child finished using the toy, and also seen when eating, the child still yet able to open and close again where the food is stocked and the child has not been able to clean up the rest of the food scattered and throw it into the trash. (3) Controlling emotions, there are 8 of 12 children or $66.66 \%$ who are still not able to control his emotions seen when children are asked to wash hands before and after meals, there are children who want to rush and do not want to queue with friends. Also seen when children are in the class, not able to use toys alternately with friends, their egoism still very high, the aspect of cooperation has not been seen.

\section{Literature Review}

\subsection{Independence}

Independence is the ability to do the task yourself, take care of yourself, and start the project without always be given the form to do [3]. The independence in question includes self-mastery skills such as dressing, health (using toilets, washing hands, and brushing teeth), and eating (using tools and aprons, taking care of themselves, and cleaning up). Independence is a trait that can be formed by parents in building the personality of their children. An independent child is an active, independent, creative, competent, and spontaneous child. This is in line with the statement that self-reliance is the ability to direct oneself to self-control, standing on their own feet. More broadly, independence is the ability to direct and control one self in thinking and acting, and not feeling emotionally dependent on others [4], [5]. This confirms that self-reliance can also help the child to learn a sense of responsibility. When the child is able to choose for himself what he wants to do right then the child learns to be responsible for his choices [6]. Independence is the freedom of the human individual to choose, to become a unity that can rule, dominate and define himself. The process of choosing is inseparable from the cognitive process in considering alternatives that are always associated with the value system. The development of independence is a process that concerns the normative elements. This implies that independence is a directional process, whereby the development of independence is in line with the existential nature of man, then the direction of development must be in line with and based on the purpose of human life [7], [8].

\subsection{Storytelling}

In teaching and learning activities a teacher's success in conveying learning is influenced by the method used because of the expected ability to be owned by the child will be determined by relevance use of a method that is in accordance with the purpose, which in its 
function is a tool to achieve goals [9]. The more accurate the method, the more effective it is expected to achieve the goal [10]. Storytelling is a way to pass the cultural heritage from one generation to the next. This opinion can be interpreted as a way of preserving culture down from previous generation to next generation [11]. Storytelling is speaking art or storytelling tells a story or an imaginative story in front of many people, usually face to face is (to differentiate with the film or drama performance in the meaning of storytelling generally) [12]. Based on the theories above, it can be concluded that storytelling is as a way of art to convey knowledge, feelings, thoughts and ideas by passing culture to the next generation orally. In addition, storytelling can also be used as a fun tool to increase independence in children because through stories the child does not feel being advised or patronized.

\section{Method}

The research method used in this research is action research method using Kurt Lewin design through 4 spiral stages: 1) planning; 2) the implementation of the action; 3) observation; and 4) reflection. Action was given to 12 children in Group A Child Early Childhood Serang City for 16 times meeting with 2 cycles i.e. 8 actions in cycle I and 8 action in cycle II. Classical success follows George E. Mills in his research of 71\% . Data collection techniques used in this study are observation, interview notes and documentation notes. Observations are made using field notes to record activities consisting of written notes on what the researchers see, hear, experience and think about in order to collect data. Interviews were conducted to the principal and teachers and children to obtain in-depth information about the development of independence from activities with the method of storytelling. Documentation note in this research is collecting information about progress reports independence of children through photos and video.

\section{Results and Discussion}

The focus of independence conducted in this research is on the aspects 1) to make choices, 2) responsible aspects and 3) aspects of controlling emotions. The results showed that the independence of children has begun to increase from each meeting conducted from the pre cycle to the second cycle. The average child self-reliance score expected in the research action hypothesis is at the evolving stage as expected (BSH). The planned action plan can improve the independence of the children of A Early childhood education programs Children of Serang City Serang City Academic Year 2015/2016. The average score of independence score of children of group A Early childhood education programs Anak Bangsa of Serang City in precycle is in the category of undeveloped (BB) with grade average score of 29.58. Observation on 12 children of group A showed that CWS got the lowest score with score of 22 and DM got the highest score of 49. Scores of 12 children were: AWW 40; AKC 26; CMA 29; CWS 22; CRH 27; DM 49; FRS 26; MYQ 24; MMH 38; MPS 24; MDS 23; and NFK 27. Based on the preliminary assessment results of the researchers and collaborators, both conclude that the independence of the child is still very low and will be given action on cycle I through the method of storytelling. The assessment result after giving the action in cycle II is presented in the table as follows: 
Table 1. Independence of Children in Cycle II Group A PAUD Anak Bangsa Serang

\begin{tabular}{|c|c|c|c|c|c|c|c|c|c|c|}
\hline \multirow[b]{2}{*}{ No } & \multirow{2}{*}{$\begin{array}{l}\text { Name of } \\
\text { responden } \\
t\end{array}$} & \multicolumn{2}{|c|}{ Pre-cycle } & \multicolumn{2}{|c|}{ Cycle I } & \multicolumn{2}{|c|}{ Cycle II } & \multirow{2}{*}{$\begin{array}{c}\text { pre- } \\
\text { cycle- } \\
\text { cycle I }\end{array}$} & \multirow{2}{*}{$\begin{array}{l}\text { cycle I } \\
\text { - cycle } \\
\text { II }\end{array}$} & \multirow{2}{*}{$\begin{array}{c}\text { Increase } \\
\text { Pre } \\
\text { Cycle- } \\
\text { cycle II } \\
\end{array}$} \\
\hline & & Score & Ex & Score & Ex & Score & Ex. & & & \\
\hline 1 & AWW & 40 & $\mathrm{MB}$ & 46 & BSH & 52 & BSH & 6 & 6 & 12 \\
\hline 2 & $\mathrm{AKC}$ & 26 & BB & 34 & MB & 49 & BSH & 8 & 15 & 23 \\
\hline 3 & CMA & 28 & BB & 36 & MB & 47 & BSH & 8 & 11 & 19 \\
\hline 4 & CWS & 22 & BB & 25 & $\mathrm{BB}$ & 30 & $\mathrm{BB}$ & 3 & 5 & 8 \\
\hline 5 & CRH & 27 & BB & 38 & MB & 48 & BSH & 11 & 10 & 21 \\
\hline 6 & DM & 50 & BSH & 52 & BSH & 53 & BSH & 2 & 1 & 3 \\
\hline 7 & FRS & 26 & BB & 30 & BB & 48 & BSH & 4 & 18 & 22 \\
\hline 8 & MYQ & 24 & BB & 28 & BB & 36 & MB & 4 & 8 & 12 \\
\hline 9 & MMH & 38 & MB & 44 & BSH & 52 & BSH & 6 & 8 & 14 \\
\hline 10 & MPS & 24 & BB & 30 & $\mathrm{BB}$ & 41 & MB & 6 & 11 & 17 \\
\hline 11 & MDS & 23 & BB & 29 & BB & 46 & BSH & 6 & 17 & 23 \\
\hline 12 & NFK & 27 & BB & 40 & MB & 48 & BSH & 13 & 8 & 21 \\
\hline \multicolumn{2}{|c|}{ Average } & 29,58 & BB & 36 & MB & 45,83 & $\mathrm{BSH}$ & 6,42 & 9,83 & 16,25 \\
\hline
\end{tabular}

If poured in the form of data independence data of children group A PAUD Anak Bangsa Serang City of Academic Year 2015/2016 in cycle II is as follows:

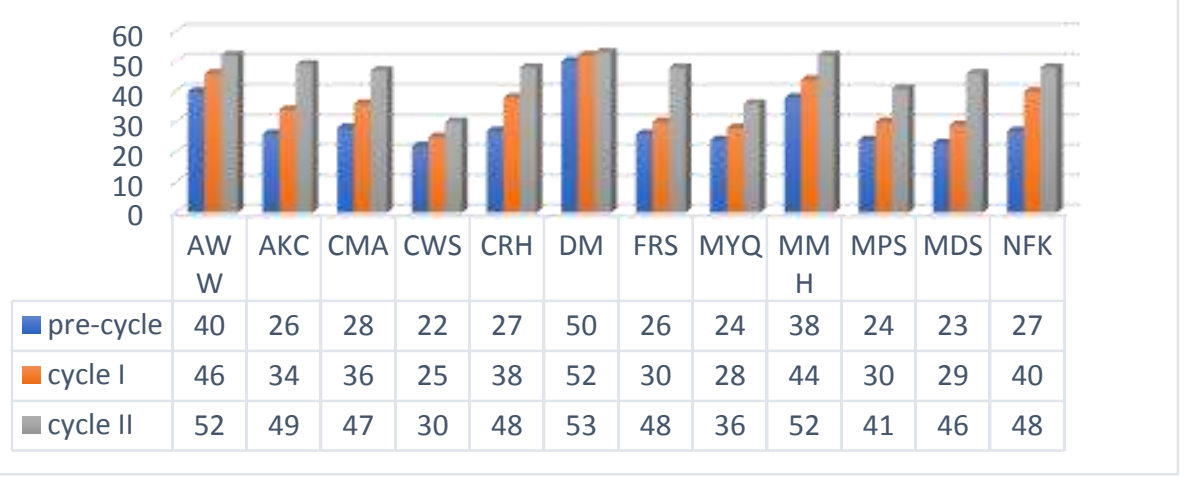

Fig. 1. Score on Cycle II, in Group A PAUD Anak Bangsa Serang

The data in the tables and graphs above show the average score for children's independence from the ninth meeting (IX) until the sixteenth meeting (XVI). The scores achieved are as follows: AWW 52; AKC 49; CMA 47; CWS 30; CRH 48; DM 53; FRS 48; MYQ 36; MMH 52; MPS 41; MDS 46 and NFK 48. As for the average TCP is 45.83 thus there are 10 children who achieve success score action or $85 \%$ of children have achieved the expected score. Thus this study has reached the standard $71 \%$ determined by Mills so no further action is required. So the researchers decided not to continue the action to the next cycle. In addition, researchers and collaborators have monitored the percentage increase that occurred in each cycle of 16.25 and can be said to be significant. For that researchers and collaborators agree to stop at cycle II, in accordance with the target in cycle I, that is if the 
child's independence continues to increase and the score obtained by the child up to the terms agreed by the researchers and collaborators, the percentage increase is significant.

Table 2. Analysis of Independence Improvement on Pre-Cycle, Cycle I and Cycle II, in Group A PAUD Anak Bangsa Serang

\begin{tabular}{cccc}
\hline Pre-Cycle & Cycle I & Cycle II & Increase \\
\hline 29,58 & $\mathbf{3 6}$ & $\mathbf{4 5 , 8 3}$ & $\mathbf{1 6 , 2 5}$ \\
\hline
\end{tabular}

Based on the above table can be seen an increase from the pre-action to the second cycle related to the independence of children with an average score of 16.25 from the initial score on the pre-action of 29.58 increased by 5.42 to 36 . And from cycle I to cycle II increased by 9.83 to equal to 45.83. Independence in the aspects of choice is important to develop, demonstrated by the ability of children to adjust to the environment and able to choose activities in accordance with his wishes are shown through: able to part with the introduction / parents, able to put the bag in place and able to reenter the classroom, able march well, choose the stationery to use and be able to feed themselves.

Independence on responsible aspects developed in children aged 4-5 years is that children have their own experience to be responsible for what he did for the future. This is in accordance that responsibility is the ability to respond, because it is directed to the obligation to care for each other and to nurture the well-being of others [10], [13] In this case independence is the ability associated with values associated with conscience and relationships with humans. The values associated with the heart are: self-awareness, responsibility, discipline, mutual respect, and mutual help. Awareness of self-potential is helping yourself, and learning to grow self-esteem. Social skills include: empathy and able to cooperate. Independence is the most important thing in education, therefore one that must be controlled by the child is the ability of independence. The child's independence in the emotional control aspect is demonstrated by the child's ability to perform activities with predetermined time and the ability of the child to share with his / her friends. In this research, children in hand washing activity before and after meal, able to exit class in turn, then can share food with friends, able to play together, and able to answer questions asked by the teacher.

\section{Conclusion}

The process of applying the action with the storytelling method conducted for 2 cycles consists of 16 times the action. The process of this activity is comprehensive in each of its actions consisting of: a) initial activities include teachers building apperception of the theme and task that will be done today, b) core activities include the implementation of action by the method of telling stories, and c) the final activity includes follow-up of activities core. The results showed an increase in the independence of children with the method of telling stories. The improvement of the result of observation of pre-action average score of 29.58 , cycle I average score increased by 5.42 to 36 and cycle II score increased by 9.83 ie score become equal to 45,83 . This study achieved the target set by Mills $71 \%$ of the total number of children i.e. 10 out of 12 children had reached the minimum TCP score of 38 or $75 \%$ of the maximum TCP 54. 


\section{References}

[1] Y. Anita, Model Pendidikan Anak Usia Dini. Jakarta: Kencana Prenada Media Group (2005)

[2] S. G. Morrison, Basic Fundamentals Of Early Childhood Education. fifth edition. Jakarta: Indeks (2012)

[3] H. B. Uno, New Orientation in Learning Psychology. Jakarta: Bumi Aksara.

[4] S. Carol, S. Castie, and R. C., Social Studies For The Presschool/Primary Child Eight Edition. New Jersey: Pearson Education Ltd (2010)

[5] M. S. Sumantri and R. Rachmadtullah, "The effect of learning media and self regulation to elementary students' history learning outcome," Adv. Sci. Lett., vol. 22, no. 12, pp. 4104-4108 (2016)

[6] Desmita, Psikologi Perkembangan Peserta Didik. Bandung: PT Remaja, 2012.

[7] M. Sumantri and N. Syaodih, Perkembangan Peserta Didik. Jakarta: Universitas Terbuka (2006)

[8] M. M. Mamahit, "Increasing Senior High School Students' Ability In Speaking English Through Contextual Storytelling Method," J. Educ. Sci. Technol., vol. 3, no. 3, p. 190, Nov (2017)

[9] H. L. Jackman, Early Education Curriculum A Child's Connection To The Wolrd, Fifth Edition. USA: Wadsworth Cengange Learning (2012)

[10] Y. N. Sujiono, Konsep Dasar Pendidikan Anak usia Dini. Jakarta: Indeks, 2009.

[11] W. Crain, Theories of Development Concept and Applications Fifth Edition. New Jersey: Pearson (2005)

[12] J. A. Brewer, Introduction to early childhood education: Presschool through Primary Grades 6th Edition. United States of America: Pearson (2007)

[13] J. W. Santrock, Educational Psychology. McGraw: Hill Medical Publishing (2011) 